\title{
Divine diseases
}

\section{An act of faith}

\section{lan Watson}

If God made man in His own image, what does that say about God's own anatomy?

When God made the world in 4004 BC, He was a young god, His rapidly inflating cosmic playground newly budded from the divine multiverse. Yet already He was wisely conscious of health issues and of a need for medical insurance. Ailments, of course, could not kill Him; divine diseases would be similar to the case of Prometheus and his pecked liver, which rapidly regenerated.

Yet why should He suffer unnecessarily?

Health care would come courtesy of His humans who would (in His own image) duly display all the ailments to which He might become vulnerable. As a result of their short lifespans, human beings would express much more rapidly, not to mention repeatedly, the ailments that might later assail Him, and would in due course, as civilization advanced, develop medical science with which to combat those ailments.

Dyspepsia and juvenile boils and acne afflicted the adolescent God badly during the days of the ancient Israelites, resulting in plagues and anger and storms and afflictions visited upon the antique, although simultaneously early, world. But presently Greeks such as Hippocrates and Theophrastus pioneered medical science, rooted in a notion of humours, which wasn't so far off course as God could be choleric, spleenful or melancholic $(\mathrm{He}$ never slept) and bilious (all those black holes in His cosmos, like stomach ulcers; all those luridly red and purple nebulae, like diseased organs of gas). Of course He could also be blessedly phlegmatic or sanguine (yet sanguine sometimes meant bloody-minded - blame not God, but rather the quirks of His physiology).

Consequently Greek diagnoses and cures, and those of the Arabs thereafter, were fairly sensible, although lacking sophistication and technology, which was what God awaited.

During a phlegmatic and benevolent era, God gave rise to His Son in a human body to bestow divine love upon His creation. However, in the long run this proved to be a serious mistake...

The problem wasn't that His Son was ungratefully crucified, to be resurrected and taken up bodily into Heaven; He would come again when the time was ripe. However, kicking off with the

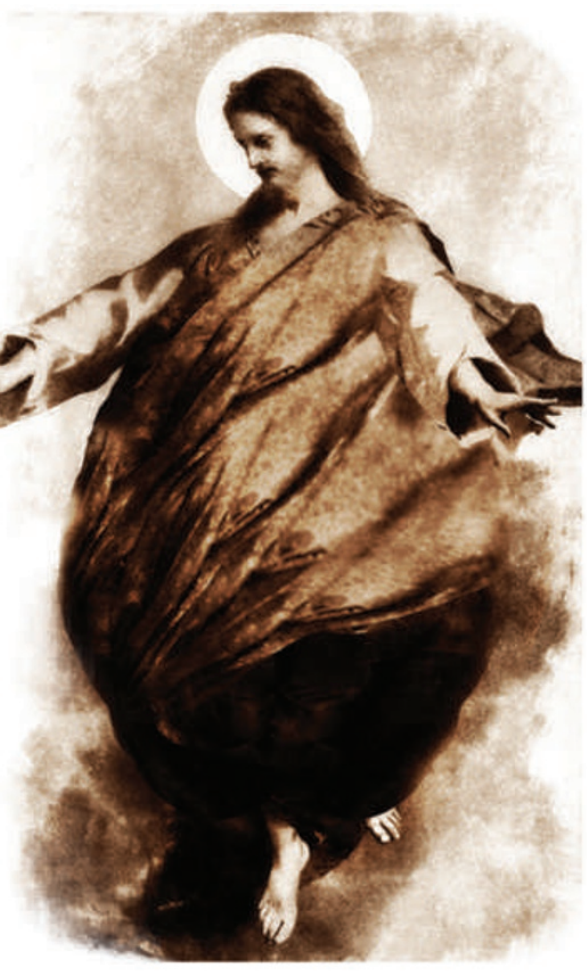

Council of Ephesus in AD 431, and then proclaimed by the Fourth Lateran Council in 1215 under Pope Lunaticus, and fully ratified officially in the sixteenth century at the Council of Trent, the Catholic Church (and the unorthodox Orthodox churches too, in their own fashions) ordained that the bread and wine consumed in communion were miraculously transubstantiated into genuine flesh and blood.

Faith may move mountains, especially a little at a time. The weight of an individual wafer was only a few grams, but a million wafers per day would in due course add up to metric tonnes. In Heaven, alongside His Father, the Son began putting on weight as the transubstantiated bread (and subsequently wafers) became added to His body mass. Likewise the blood, to sustain the supplementary tissue. Be it noted that the newly created flesh must needs be transferred to the Son in Heaven after ingestion but before digestion; otherwise the divine flesh must pass onward into the bowels and become what normal nutrition normally becomes; which would be sacrilegious.

This weight gain didn't matter too much to begin with, as the Son had been fairly gaunt, just as most Palestinians were at the time of His birth. Not to mention that $\mathrm{He}$ was fairly tall (think El Greco). He could benefit by some additional bodily tissue.

However, fast-forward a few hundred years more to the time when the numbers of the human race began to climb almost exponentially - half a billion, two billion, six billion. Many of these souls were occasional or even daily transubstantiators. (The Protestant Reformation might in this light be viewed as a slimming campaign, as Protestantism denied that bread and wafers actually changed; therefore they did not do so.)

Despite pruning of population by wars and, more effectively, by plagues such as the otherwise inexplicable Spanish influenza pandemic in the wake of the First World War, the Son's body mass in Heaven was increasing alarmingly. From overweight, to positively obese.

Yet God delayed the Second Coming because only now was medical science really getting into its stride. Penicillin and subsequent pharmaceuticals, radiotherapy, open-heart surgery, transplants, DNA diagnoses and all the other wonders of medical science: just wait another 50 years, and all of God's increasing bodily woes could be cured by His clever creatures who were both the laboratory rats for the ailments and the researchers into cures.

Wait a few more years. Yet because of transubstantiation, the obesity problem of the Son was becoming dire.

Finally the Second Coming was triggered prematurely by sheer geometrical and gravitational stress. As a result of the accumulated bulk of the Son, amounting by now to hundreds of metric tonnes, $\mathrm{He}$ couldn't reappear anywhere on the surface of Earth in a dignified way - Him with his vastly bloated body, out of which protruded a normal-sized head and hands and feet - nor perhaps without succumbing to an immediate heart attack.

Accordingly, it was in near-Earth orbit that the Second Coming occurred, a shining Jesus moonlet with its own miraculous warm atmosphere, rivalling Luna much farther away.

And the messages began: Stop Transubstantiating! Too Much Mass!

Ian Watson's most recent book The Beloved of My Beloved (NewCon Press, 2009), written with Italian surrealist Roberto Quaglia, may well be the first full-length genre fiction work by two authors with different mother tongues. Join the discussion of Futures in Nature at go.nature.com/QMAm2a 